\title{
Temporary Shelter Simulation Towards Effectiveness Value of OTTV and Thermal comfort
}

\author{
Dyah Puspa Ayu ${ }^{1, *}$, Budi Prayitno $^{2}$, and Agus Hariyadi ${ }^{2}$ \\ ${ }^{1}$ Digital Object Oriented Research and Experiment Laboratory, Department of Architecture and Planning Engineering, Faculty of \\ Engineering, Universitas Gadjah Mada, Jl. Grafika No. 2, Yogyakarta 55281, Indonesia \\ ${ }^{2}$ Department of Architecture and Planning Engineering, Faculty of Engineering, Universitas Gadjah Mada, Jl. Grafika No. 2, Yogyakarta \\ 55281, Indonesia \\ ${ }^{*}$ Corresponding author: dyah.puspa.ayu@gmail.com
}

\author{
KEYWORDS \\ Temporary shelter \\ Transition phase \\ Material \\ OTTV \\ Thermal comfort \\ Grasshopper
}

\begin{abstract}
Indonesia is prone to a variety of natural disasters, one of which is earthquakes. Earthquakes are detrimental to human life, causing among other things a loss of shelter. As such, victims of earthquakes need basic assistance in the form of shelter, which the Indonesian government provides in the transition phase of emergency responses. Several innovations in the provision of temporary shelter have arisen in terms of packaging and fast unloading. This research aimed to examine the effective value of OTTV energy (overall thermal transfer value), differences in room temperature, and thermal comfort in existing temporary shelters. OTTV values and thermal comfort are adapted to Indonesia's humid tropical climate, which has a temperature ranging $24-30^{\circ} \mathrm{C}$ and air humidity of $75 \%$. Temporary shelters were simulated with Rhinoceros and Grasshopper softwares. The simulation was carried out in two stages, with the first stage simulating the temporary shelter materials and the second stage simulating according to a predetermined standard. The results concluded that the effective value of OTTV with the use of Styrofoam-based shelter gives a value of $27.63 \mathrm{~W} / \mathrm{m}^{2}$ with a decrease of up to $4.70 \mathrm{~W} / \mathrm{m}^{2}$, and the temperature drops to $2-3^{\circ} \mathrm{C}$.
\end{abstract}

(๑) The Author(s) 2019. This article is distributed under a Creative Commons Attribution-ShareAlike 4.0 International license.

\section{INTRODUCTION}

Earthquakes are one of the disasters caused by tectonic movements (Boen 2016). Indonesia is a country that has earthquake potential, and has experienced 143 earthquakes since 2009-2018, as explained by the Indonesian National Board for Disaster Management (Badan Nasional Penanggulangan Bencana, or BNPB).

The damage caused by earthquake is detrimental to the environment, one of which is the loss of a place to live and requires the victims to live in a refugee tent (Rizal and Tavio 2014). Shelter is a basic need for humans, therefore, a help to build a shelter requires a short amount of time. Victims who stay too long in the evacuation tents will have a devastating effect on their psychic, therefore, during the emergency response phase, temporary shelter is needed (Akhmad and Fachruddin 2008; Mahira and Hignasari 2018; Rizal and Tavio 2014). Because the main function of the refugee tent only serve as a temporary emergency tent (Santoso et al. 2016). Temporary shelters have a period of stay of 12 months to 18 months (Affisa and Djunaedi 2014).

Temporary shelter assistance in the post-disaster stage in Indonesia has been widely carried out, one of which is temporary shelter assistance in Gondang. The temporary shelter uses bamboo materials (Putro and Roychansyah 2012). Innovations for temporary shelters have been made in terms of practicality of these shelters, with the aim of installing temporary shelters that is quick, efficient, and effective, and prioritizing reusable materials (Affisa and Djunaedi 2014; Mahira and Hignasari 2018; Santoso et al. 2016).

The problem of this research is to find out the effective value of OTTV (overall thermal transfer value) energy and the value of thermal comfort of temporary shelter materials, which are adjusted to the climate characteristics in Indonesia. The optimum value of OTTV and thermal comfort is done by simulation using Rhinoceros and Grasshopper as an analytical aid. Use this software to help the analysis by using a temporary shelter model by comparing the results of a predetermined temporary shelter model to see the effective value of OTTV and thermal comfort.

\section{MATERIALS AND METHODS}

\subsection{Data sampling}

Temporary shelter samples are taken from some literature that has discussed temporary shelter by looking at the variables and indicators that have been determined and noted as shown in Table 1.

In addition, the samples are also viewed from the standard set by BNPB and UNHCR that provide safety requirements, ensure privacy, sized $3 \mathrm{~m}^{2}$ per person, and minimum space of $18 \mathrm{~m}^{2}$ which can accommodate 4-5 people. The distribution of temporary shelter can be at least distributed using pickup truck. 
TABLE 1. Variables and indicators for the selection of temporary shelter samples.

\begin{tabular}{ll}
\hline Variables & Indicators \\
\hline Effective and efficient & Quick, light \\
Economical & Pre-fabrication, distribution \\
Durability & Materials \\
Safety & Strong/durable \\
System & Modular (connection) \\
\hline
\end{tabular}

TABLE 2. Selecting temporary shelter samples.

\begin{tabular}{|c|c|c|c|}
\hline Sample & Width $\left(\mathrm{m}^{2}\right)$ & Distribution & Capacity \\
\hline A & 12 & Pick up & 4 people \\
\hline B & 18.91 & Pick up, truck & 5 people \\
\hline C & 18 & Truck & 4 people \\
\hline D & 19.44 & - & 1-3 people \\
\hline $\mathrm{E}$ & 32.4 & - & 4-6 people \\
\hline $\mathrm{F}$ & 38.88 & - & $>7$ people \\
\hline G & 115.93 & - & 2 main family \\
\hline $\mathrm{H}$ & 21 & Pick up, truck, ship, plane & 5 people \\
\hline I & 14.76 & Container truck & 4 people \\
\hline J & 35 & - & 5 people \\
\hline
\end{tabular}

From the results of the literature, 10 samples of temporary shelter that meet the variables and indicators were found (Table 2). Then it is sorted again according to the criteria for the standard area, capacity, distribution of temporary shelters, and temporary shelter packaging systems using 1:50 scale mock-ups. This was done to see the dimensions of the temporary shelter and the effective level of making the temporary shelter. After doing this method, four temporary shelter samples were found to be in accordance with the minimum standard of temporary shelter.

Sample A is a temporary shelter designed to be assembled and disassembled quickly within two hours by six people applicators. Sample A is included in the selection because the packaging system and material usage are taken into account. It uses the lightweight, durable, strong, and anti-rust materials (Santoso et al. 2016).

Sample B has a bracket with bolt reinforced connection system on its frame. The use of a lightweight material adds value to sample B. The temporary shelter concept of sample $B$ is one of a portable building with a size of $3.05 \mathrm{~m} \times 6.20$ $\mathrm{m}$, which can accommodate five people (Irwan et al. 2016).

Sample C is a temporary shelter in Korea. This temporary shelter can function for more than six months after being built. As well as using materials that can be fabricated, such as metal-based materials, it has a dwelling size of 18 $\mathrm{m}^{2}$ (Moon and Lee 2007).
Sample H is a temporary shelter by cmax shelter, which has the concept of tents and trailers, a house that can be moved and built anywhere. The module used is $3 \mathrm{~m}$. Because the packaging system is folding, the resulting occupancy volume is $9 \mathrm{~m}^{3}$ per unit. Sample $\mathrm{H}$ can be assembled in 11 minutes with two adult applicators (Pero 2014).

\subsection{Sample analysis on OTTV values}

OTTV (overall thermal transfer value) is a value of overall thermal transfer by showing the results of heat recovery caused by solar radiation at each value per square meter of wall area (Satwiko 2009). Standard OTTV in Indonesia since 2011 has set at $35 \mathrm{~W} / \mathrm{m}^{2}$ (Hariyadi et al. 2017; Setiani et al. 2017). The OTTV standard aims to make an impact on the energy use in order to prevent an excessive use of energy (Setiani et al. 2017).

The use of OTTV analysis aims to determine the optimum value of energy in temporary shelter samples by knowing the value of WWR (window to wall ratio) and the characteristics of the materials used in temporary shelter samples. The OTTV formula is as follows (Equation 1).

$$
\mathrm{OTTV}_{\mathrm{n}}=\alpha\{U(1-\mathrm{WWR})\} \cdot \Delta \mathrm{T}_{\mathrm{eq}}+(\mathrm{SC})(\mathrm{WWR})(\mathrm{SF}) \mathrm{W} / \mathrm{m}^{2}
$$

For WWR values and material characteristic values in samples A, B, C, and $\mathrm{H}$ are selected as shown in Table 3.

WWR (window to wall ratio) value and material characteristic values are needed to run an experimental simulation using Rhinoceros and Grasshopper by adding the EnergyPlus, Ladybug, and Honeybee plugins (Table 4).

\subsection{Sample analysis on thermal comfort}

Thermal comfort in a shelter is important. It is determined by looking at the factors that affect thermal comfort, such as air temperature, wind speed, air humidity, average room temperature, human activities, and clothing used.

The thermal comfort of space can be formed using natural (cross ventilation) and artificial ventilation. But artificial ventilation will add value to the cost and energy in the room (Satwiko 2009).

Thermal comfort in tropical and humid tropics is different. Tropical temperature ranged $23.3-29.4^{\circ} \mathrm{C}$ with a humidity of 30-70\% (Olglay 2015). Whereas in humid tropics, the temperature ranged $27-32^{\circ} \mathrm{C}$ with a limit of $24^{\circ} \mathrm{C}<\mathrm{T}<$ $26^{\circ} \mathrm{C}$ and at $24^{\circ} \mathrm{C}$, it can be said to be cool with a humidity $40 \%<\mathrm{RH}<60 \%$ (Satwiko 2009). The temperature range of Jakarta is between $24^{\circ} \mathrm{C}$ and $30^{\circ} \mathrm{C}$ (Karyono 2013) with a $75 \%$ humidity (Hariyadi et al. 2017).

Professor P.O. Fanger has made a PMV (predicted mean value) scale to determine the value of comfort in a room, that is (-3) cold and (+3) hot (Satwiko 2009). PMV is an estimated indicator value of comfortable conditions for res-

TABLE 3. Temporary shelter sample materials and WWR value.

\begin{tabular}{|c|c|c|c|c|c|c|}
\hline \multirow[t]{2}{*}{ Sample } & \multicolumn{3}{|c|}{ Materials } & \multirow[t]{2}{*}{ Opening area $\left(\mathrm{m}^{2}\right)$} & \multirow[t]{2}{*}{ Wall area $\left(\mathrm{m}^{2}\right)$} & \multirow[t]{2}{*}{ WWR (\%) } \\
\hline & Wall & Floor & Roof & & & \\
\hline A & EPS (Styrofoam) & EPS (Styrofoam) & EPS (Styrofoam) & 0.98 & 39.2 & 2.5 \\
\hline B & Plastic (polypropylene) & Plastic (polypropylene) & Plastic (polypropylene) & 2.54 & 59.52 & 4.3 \\
\hline C & Metal composite & Plywood & Metal (galvanized) & 5.408 & 63 & 8.6 \\
\hline $\mathrm{H}$ & Membrane & Plastic (polypropylene) & Membrane & 0.84 & 60 & 1.4 \\
\hline
\end{tabular}


TABLE 4. Characteristic values of temporary shelter sample materials.

\begin{tabular}{lclcc}
\hline Material & Thickness $(\mathrm{m})$ & Roughness & Conductivity $(\mathrm{W} / \mathrm{m}-\mathrm{K})$ & Density $\left(\mathrm{kg} / \mathrm{m}^{3}\right)$ \\
\hline EPS & 0.03 & Medium smooth & 0.033 & 8 \\
EPS & 0.07 & Medium smooth & 0.033 & 1170 \\
Plastic & 0.1 & Smooth & 0.2 & 1170 \\
Plywood & 0.018 & Medium smooth & 0.15 & 1925 \\
Galvanized & 0.0005 & Rough & 15.1 & 700 \\
Metal composite & 0.005 & Rough & 15.1 & 7135 \\
Membrane & 0.0005 & Smooth & 0.15 & 7850 \\
\hline
\end{tabular}

idents while carrying out activities associated with PPD (predicted percentage of discomfort) (Karyono 2013).

\section{RESULTS AND DISCUSSION}

\subsection{First stage simulation}

The selected temporary shelter samples will be simulated in the first stage using Rhinoceros and Grasshopper. To find out the effective value of OTTV, a plugin is added to the Grasshopper program, namely Honeybee. Because sample A has $12 \mathrm{~m}^{2}$, an analysis of sample A is carried out by modifying it to $18 \mathrm{~m}^{2}$ so that the dimensions are in accordance with the minimum standards specified by the law and UNHCR. The accuracy of OTTV values will be viewed using six different directions, north, northeast, east, southeast, south, and west (Figure 1). The simulation will be processed within one year and done by comparison using standard materials in order to know the difference in value produced.

The results of the calculation of energy simulation generated by both OTTV values in the four temporary shelter samples are as follows.

Each sample will be simulated by inserting material into each one of them. For example, sample A will receive material of samples B, C, and H. Comparison is done by finding the value of ETTV (envelope thermal transfer value) to determine the differences in the optimum value between OTTV and ETTV in each materials. In addition to simulating the optimum value of energy, a simulation is carried out to determine the value of the temperature difference indoors and outdoors with the same criteria, that is, each temporary shelter sample receives all materials. The value

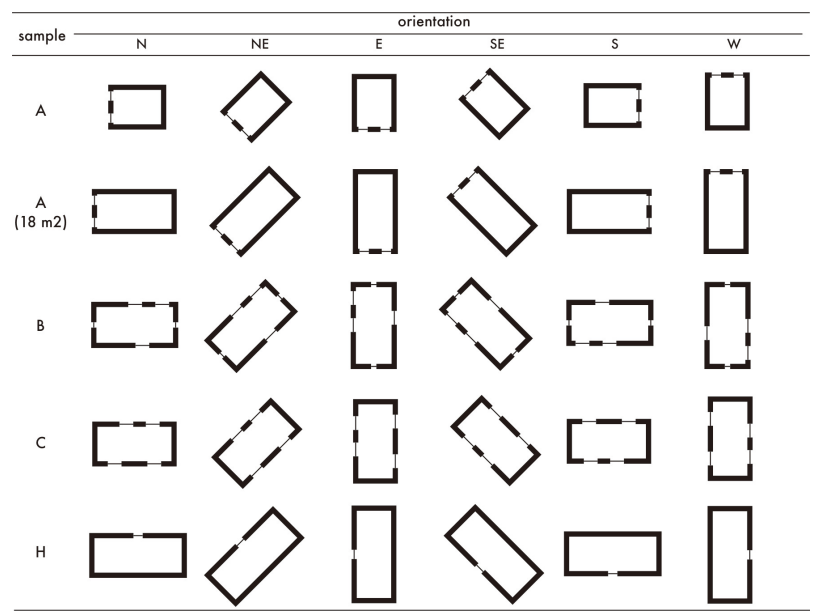

FIGURE 1. Direction of the opening in temporary shelter is in accordance with the direction of the compass. displayed is the lowest value for each simulation and the position of the temporary shelter that has the lowest value. The simulation is assumed to use AC (air conditioner) and glare glass in each temporary shelter sample. This is done to determine the use of energy and the differences in temperature values in temporary shelter samples.

The next simulation result is an overheated PMV that displays visual comfort in the temporary shelter based on the materials used in each sample.

\subsection{Second stage simulation}

The second stage simulation is performed to find out the effective value of energy, OTTV, and thermal comfort accurately. The second phase of the simulation is still using Rhinoceros and Grasshopper, but the samples are narrowed to only two temporary shelter samples. Table 7 shows the second stage simulation scenario.

Simulation scenario is a selected sample with occupancy area approaching the standard that is $18 \mathrm{~m}^{2}$. The materials used are only 3 of the 4 existing materials. The membrane material is not used because of the membrane material character which cannot reduce heat well. Sample A which has been modified is also included in the second stage of the simulation as a comparison. Besides paying attention to the area, we also see the value of WWR in each temporary shelter sample. The following are the results of the second phase simulation.

The second round of the second stage simulation is carried out to strengthen the results of the simulation. The simulation is done according to the scenario in the second stage. The results of OTTV values, temperature differences, and overheated PMV are as follows.

\subsection{OTTV energy}

There is a difference in the results between the first and second stage of the energy simulation. In the first stage, the OTTV value on temporary shelter sample A $\left(18 \mathrm{~m}^{2}\right)$ has the lowest OTTV value of $18.87 \mathrm{~W} / \mathrm{m}^{2}$, whereas the sample $B$ reached $47.62 \mathrm{~W} / \mathrm{m}^{2}$ (Table 5 ). It indicates that sample $\mathrm{B}$, by using plastic (polypropylene) material, does not meet established standards.

When the simulation is done by applying the materials to all temporary shelter samples, the lowest OTTV value was obtained from using EPS materials based on Styrofoam, with a westerly orientation on the sample A, and southward on the sample B, C, and H. However, sample B decreased from $47.62 \mathrm{~W} / \mathrm{m}^{2}$ to $46.32 \mathrm{~W} / \mathrm{m}^{2}$, but it still has not reached the standards determined that is $35 \mathrm{~W} / \mathrm{m}^{2}$.

The second stage simulation is carried out with two scenarios, showing significant differences between the first and the second stage simulation. Especially in sample C, the energy decreased to $4.70 \mathrm{~W} / \mathrm{m}^{2}$ when EPS material is 
TABLE 5. Results of OTTV energy simulation values of the temporary shelter samples.

\begin{tabular}{|c|c|c|c|c|c|c|c|c|c|c|c|c|c|c|}
\hline \multirow[t]{2}{*}{ Sample } & \multirow[t]{2}{*}{ Material } & \multicolumn{6}{|c|}{ Energy simulation $\left(\mathrm{kWh} / \mathrm{m}^{2}\right)$} & \multirow[t]{2}{*}{ WWR (\%) } & \multicolumn{6}{|c|}{ OTTV $\left(\mathrm{W} / \mathrm{m}^{2}\right)$} \\
\hline & & $\mathrm{N}$ & NE & E & SE & $\mathrm{S}$ & W & & $\mathrm{N}$ & NE & $\mathrm{E}$ & SE & S & W \\
\hline \multirow[t]{2}{*}{ A } & EPS & 455.2 & 455.0 & 448.8 & 452.5 & 451.1 & 440.5 & 2.5 & 36.92 & 34.99 & 31.06 & 34.99 & 36.81 & 24.21 \\
\hline & Standard & 767.0 & 772.4 & 773.5 & 770.2 & 763.8 & 771.2 & 2.5 & 42.98 & 41.05 & 37.11 & 41.10 & 42.91 & 30.27 \\
\hline \multirow[t]{2}{*}{$A\left(18 m^{2}\right)$} & EPS & 415.0 & 418.2 & 417.2 & 416.6 & 412.2 & 411.7 & 1.94 & 28.83 & 27.29 & 24.21 & 27.30 & 28.75 & 18.87 \\
\hline & Standard & 709.8 & 721.0 & 728.9 & 719.7 & 707.7 & 727.4 & 1.94 & 33.35 & 31.79 & 28.66 & 31.84 & 33.29 & 23.32 \\
\hline \multirow[t]{2}{*}{ B } & Plastic & 616.6 & 628.7 & 638.3 & 626.7 & 613.7 & 640.7 & 4.3 & 49.08 & 50.36 & 50.61 & 48.68 & 47.62 & 50.68 \\
\hline & Standard & 741.9 & 757.8 & 770.9 & 757.3 & 740.8 & 772.5 & 4.3 & 51.36 & 52.56 & 52.74 & 50.91 & 49.11 & 58.32 \\
\hline \multirow[t]{2}{*}{ C } & $\begin{array}{l}\text { Metal } \\
\text { composite }\end{array}$ & 986.4 & 1017.4 & 1044.9 & 1019.9 & 986.4 & 1045.0 & 8.6 & 34.09 & 39.47 & 46.13 & 39.53 & 34.08 & 44.57 \\
\hline & Standard & 793.4 & 816.3 & 836.4 & 817.4 & 793.4 & 836.3 & 8.6 & 33.57 & 39.05 & 44.32 & 40.13 & 33.56 & 46.93 \\
\hline \multirow[t]{2}{*}{$\mathrm{H}$} & Membrane & 873.1 & 902.8 & 929.4 & 904.5 & 872.3 & 929.9 & 1.4 & 18.36 & 19.33 & 19.58 & 17.58 & 16.03 & 19.65 \\
\hline & Standard & 706.3 & 721.4 & 734.3 & 720.8 & 705.2 & 735.8 & 1.4 & 15.63 & 15.01 & 17.28 & 13.73 & 13.32 & 17.31 \\
\hline
\end{tabular}

placed in the temporary shelters (Table 8). Whereas in the next simulation (Table 9), sample B decreased to $3.60 \mathrm{~W} / \mathrm{m}^{2}$ from the previous simulation (Table 8). This shows that the EPS material gives influence in terms of the energy used in temporary shelter samples.

\subsection{Comparison of indoor and outdoor air temperatures}

The simulation results on differences in indoor and outdoor air temperatures, using a reference location in Jakarta, Indonesia, which has a temperature range of $24-30^{\circ} \mathrm{C}$ Karyono (2013). It is explained in Table 6 that the sample of temporary shelter using EPS material has a difference in temperature of the air temperature inside and outside up to $2-3^{\circ} \mathrm{C}$. With the orientation of occupancy facing west for sample A and south for samples B, C, and $\mathrm{H}$. The plastic material (polypropylene) has a difference up to $0.55-1.14^{\circ} \mathrm{C}$. The temperature value of composite metal and membranes do not have significant results. The results show that indoor temperature of the temporary shelter is hotter than the outdoor temperature.

In the second stage of the simulation carried out with a scenario (Table 7), it shows the temperature in the room fell to $0.96^{\circ} \mathrm{C}$ between the temperature inside and outside in sample B. When compared with the results of the first stage of simulation, the temporary shelter samples with composite metal materials had a difference in the temperature, and the outside temperature is higher than the inside. Table 6 shows that the inner temperature reaches $28.5^{\circ} \mathrm{C}$ and outside $29.35^{\circ} \mathrm{C}$, it has a difference of $0.85^{\circ} \mathrm{C}$.

The second round of the second simulation stage results show the same thing in the previous simulation. Sample $\mathrm{B}$ decreased to $0.85^{\circ} \mathrm{C}$ and sample $\mathrm{C}$ decreased to $0.95^{\circ} \mathrm{C}$. The results from the first and second simulation stages for EPS material has a value that falls in the temperature range of Jakarta area, because the temperature range produced by EPS material is between $27.9-29.79^{\circ} \mathrm{C}$.

\subsection{Thermal comfort (overheated PMV)}

The visual result of overheated PMV in the first stage of simulation (Figure 2) shows that the temporary shelter sample A, using EPS material, has a value of $44.17 \%$ and the visual result has only a few red patches. This indicates that sample $\mathrm{A}$ is more comfortable to inhabit as a temporary shelter. When sample A was modified to $18 \mathrm{~m}^{2}$ the PMV value fell $0.74 \%$ with a whiter visual result compared to when it had an area of $12 \mathrm{~m}^{2}$. In contrast to the temporary shelter sample B, which uses plastic materials (polypropylene), shows the highest value of $68.38 \%$ in the orientation position of the east, and shows a red visual. Looking at the maximum indicator of $70.70 \%$, and sample B almost reached this number, indicating that sample $B$ is not comfortable to be inhabited as temporary shelter in humid tropics.

The second stage simulation done with the scenario (Table 7) shows different result from the first stage simu-

TABLE 6. Results of the OTTV energy simulation value and temperature by entering materials into each temporary shelter sample.

\begin{tabular}{|c|c|c|c|c|c|c|c|c|c|c|c|c|c|}
\hline \multirow{3}{*}{$\begin{array}{l}\text { Sample } \\
\\
\text { A }\end{array}$} & \multirow{3}{*}{$\begin{array}{l}\text { Orientation position } \\
\text { West }\end{array}$} & \multicolumn{3}{|c|}{ EPS } & \multicolumn{3}{|c|}{ Plastic } & \multicolumn{3}{|c|}{ Metal composite } & \multicolumn{3}{|c|}{ Membrane } \\
\hline & & \multirow{2}{*}{$\frac{\text { OTTV }}{24.21}$} & \multicolumn{2}{|r|}{ Temp. $\left({ }^{\circ} \mathrm{C}\right)$} & \multirow{2}{*}{$\frac{\text { OTTV }}{26.03}$} & \multicolumn{2}{|r|}{ Temp. $\left({ }^{\circ} \mathrm{C}\right)$} & \multirow{2}{*}{$\frac{\text { OTTV }}{31.71}$} & \multicolumn{2}{|c|}{ Temp. $\left({ }^{\circ} \mathrm{C}\right)$} & \multirow{2}{*}{$\frac{\text { OTTV }}{33.14}$} & \multicolumn{2}{|c|}{ Temp. $\left({ }^{\circ} \mathrm{C}\right)$} \\
\hline & & & In & 27.12 & & In & 29.05 & & In & 29.82 & & In & 29.98 \\
\hline & & 24.21 & Out & 30.37 & 26.03 & out & 30.19 & 31.71 & Out & 29.49 & 33.14 & Out & 29.79 \\
\hline \multirow[t]{2}{*}{$A\left(18 m^{2}\right)$} & West & 18.87 & In & 27.10 & 20.12 & In & 29.09 & 24.49 & In & 29.84 & 25.70 & In & 29.99 \\
\hline & & 18.87 & Out & 30.39 & 20.12 & Out & 30.29 & 24.49 & Out & 29.50 & 25.70 & Out & 29.79 \\
\hline \multirow[t]{2}{*}{ B } & South & 46.32 & In & 27.24 & 47.62 & In & 28.90 & 49.51 & In & 29.42 & 50.63 & In & 29.55 \\
\hline & & 46.32 & Out & 29.46 & 47.62 & Out & 29.45 & 49.51 & Out & 28.94 & 50.63 & Out & 29.16 \\
\hline \multirow[t]{2}{*}{ C } & North, south & 30.59 & In & 27.53 & 31.46 & In & 29.14 & 34.08 & In & 29.62 & 35.05 & In & 29.78 \\
\hline & & 30.59 & Out & 29.73 & 31.46 & Out & 29.68 & 34.08 & Out & 29.14 & 35.05 & Out & 29.37 \\
\hline \multirow[t]{2}{*}{ H } & South & 9.38 & In & 27.02 & 10.38 & In & 29.12 & 14.92 & In & 29.93 & 16.03 & In & 30.09 \\
\hline & & 9.38 & Out & 30.84 & 10.38 & Out & 30.15 & 14.92 & Out & 29.71 & 16.03 & Out & 30.05 \\
\hline
\end{tabular}


TABLE 7. Second stage simulation scenario.

\begin{tabular}{lllll}
\hline Sample & WWR (\%) & Layer & \multicolumn{3}{c}{ Wall materials } \\
\cline { 4 - 5 } & & & Stage 1 & Stage 2 \\
\hline A $\left(18 \mathrm{~m}^{2}\right)$ & 1.94 & Out & EPS $^{\mathrm{a}}$ & EPS $^{\mathrm{a}}$ \\
& 1.94 & In & EPS $^{\mathrm{a}}$ & EPS $^{\mathrm{a}}$ \\
B & 4.3 & out & Plastic $^{\mathrm{b}}$ & EPS $^{\mathrm{a}}$ \\
& 4.3 & In & EPS $^{\mathrm{a}}$ & Plastic $^{\mathrm{b}}$ \\
C & 8.6 & Out & Metal composite & EPS $^{\mathrm{a}}$ \\
& 8.6 & In & EPS $^{\mathrm{a}}$ & Metal composite \\
\hline
\end{tabular}

astyrofoam, ${ }^{\mathrm{b}}$ Polypropylene.

Note: The temporary shelter sample, A, did not experience the addition of wall material both on the outside and inside.

lation. The results displayed visually indicate that there is a decrease when plastic material (polypropylene) is combined with EPS material. Facing at the position of the same east direction, sample B that uses plastic (polypropylene) produces a value of $57.58 \%$, this has decreased by $10.8 \%$. The sample also shows white patches appear in the area near the opening (Figure 3).

In contrast to the visual results (Figure 4), when EPS material is placed on the outside, positioned to face the east direction, sample B shows a uniform red color. This has the same value in the first stage of the simulation using only plastic materials (polypropylene). The results produced reach $60.04 \%$ with an indicator limit of $51.69-58.77 \%$. Seeing these results, EPS material is suitable to be placed as the first layer and then the second layer of plastic.

The overheated PMV simulation results between the first and the second stage of simulation shows that EPS material can stand alone as a covering wall, and can be used as insulation in the interior of a temporary shelter, because it has a characteristic to reduce heat. In addition to the type of the material used, the number of openings and the size of the openings (WWR) used will also affect the results of comfort in the temporary shelter space.

\section{CONCLUSIONS}

The simulation results using the Rhinoceros and Grasshopper programs applied on temporary shelter samples show the effective value of OTTV energy on EPS, which is 27.63 $\mathrm{W} / \mathrm{m}^{2}$. In the second stage simulation EPS gives an impact as an insulation wall and can reduce energy up to 4.70 $\mathrm{W} / \mathrm{m}^{2}$, therefore, EPS material tends to reduce energy use in temporary shelters and enter the specified OTTV standards. Not only OTTV value, the difference between the inside and outside temperature in the temporary shelter ranged from $27.90-29.79^{\circ} \mathrm{C}$, which indicates that EPS is in-

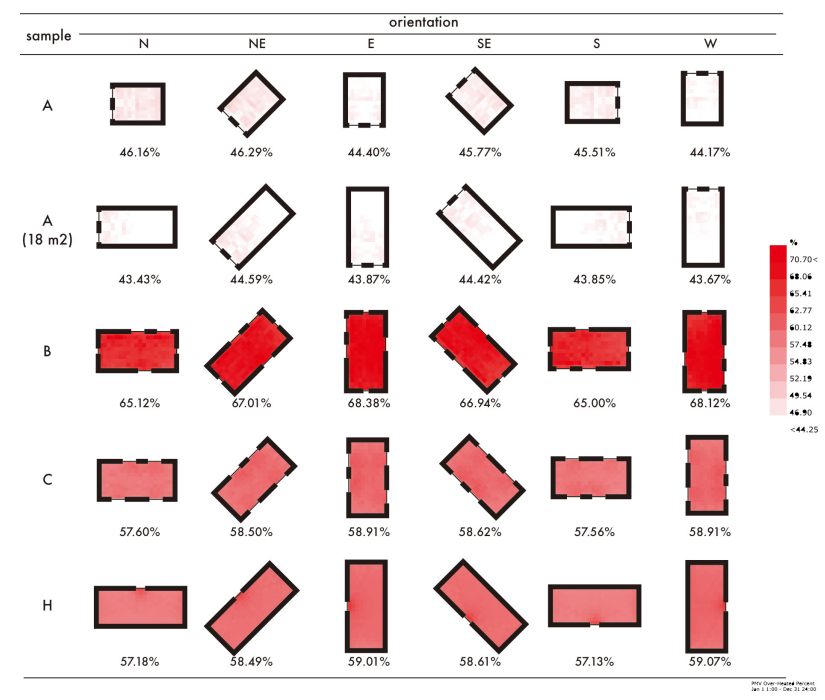

FIGURE 2. Overheated PMV simulation results for each temporary shelter sample, the value generated in the simulation ranged $44.25-70.70 \%$.

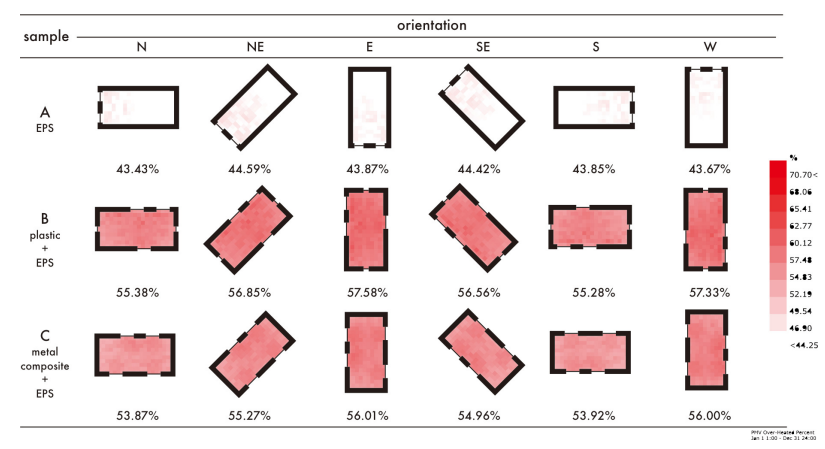

FIGURE 3. Results of overheated PMV in the first round of the second stage simulation, the value generated in the simulation ranged from 44.25-70.70\%.

cluded in the average temperature range of Indonesia's humid tropical climate and can reduce the room temperature between $2-3^{\circ} \mathrm{C}$. From the result of visual and percentage of overheated PMV, EPS material can reduce heat well.

In the first stage simulation, temporary shelter is applied with the use of materials, showing that the temporary shelter is comfortable to live in, with a little red patch marks and is dominated by white, and it reaches the value of $44.17 \%$ with an indicator of $44.25-70.70 \%$. In the second stage of the simulation with the same indicator EPS materials play a good role when being insulated or are on the side of the dwelling, because it gives a comfortable impact with marked red becomes easier and the percentage results show a decrease reaching $9.12 \%$ in sample B and $3.69 \%$ in sample $\mathrm{C}$ compared with the results of the first stage simu-

TABLE 8. First round of second simulation results of OTTV values and temperature in temporary shelter samples.

\begin{tabular}{|c|c|c|c|c|c|c|c|c|c|c|c|c|c|c|}
\hline \multirow[t]{2}{*}{ Sample } & \multirow[t]{2}{*}{ Material } & \multicolumn{6}{|c|}{$\operatorname{OTTV}\left(\mathrm{W} / \mathrm{m}^{2}\right)$} & & \multicolumn{6}{|c|}{ Temperature $\left({ }^{\circ} \mathrm{C}\right)$} \\
\hline & & $\mathrm{N}$ & NE & E & SE & $S$ & W & & $\mathrm{N}$ & NE & $\mathrm{E}$ & SE & S & W \\
\hline \multirow[t]{2}{*}{ A } & EPS & 28.83 & 27.29 & 24.21 & 27.30 & 28.75 & 18.87 & In & 27.26 & 27.26 & 27.26 & 27.22 & 27.20 & 27.10 \\
\hline & EPS & 28.83 & 27.29 & 24.21 & 27.30 & 28.75 & 18.87 & Out & 30.47 & 30.48 & 30.48 & 30.46 & 30.44 & 30.39 \\
\hline \multirow[t]{2}{*}{ B } & Plastic, EPS & 48.76 & 50.06 & 49.83 & 48.38 & 46.51 & 50.41 & In & 28.54 & 28.62 & 28.67 & 28.60 & 28.51 & 28.69 \\
\hline & Plastic, EPS & 48.76 & 50.06 & 49.83 & 48.38 & 46.51 & 50.41 & Out & 29.50 & 29.53 & 29.52 & 29.51 & 29.47 & 29.54 \\
\hline \multirow[t]{2}{*}{ C } & Metal composite, EPS & 29.38 & 35.06 & 40.46 & 35.13 & 29.38 & 0.63 & In & 28.50 & 28.67 & 28.80 & 28.67 & 28.50 & 28.81 \\
\hline & Metal composite, EPS & 29.38 & 35.06 & 40.46 & 35.13 & 29.38 & 0.63 & Out & 29.35 & 29.44 & 29.51 & 29.45 & 29.35 & 29.51 \\
\hline
\end{tabular}


TABLE 9. Second round of second simulation results of OTTV values and temperature in temporary shelter samples.

\begin{tabular}{|c|c|c|c|c|c|c|c|c|c|c|c|c|c|c|}
\hline \multirow[t]{2}{*}{ Sample } & \multirow[t]{2}{*}{ Material } & \multicolumn{6}{|c|}{$\operatorname{OTTV}\left(\mathrm{W} / \mathrm{m}^{2}\right)$} & & \multicolumn{6}{|c|}{ Temperature $\left({ }^{\circ} \mathrm{C}\right)$} \\
\hline & & $\mathrm{N}$ & NE & E & SE & $S$ & W & & $\mathrm{N}$ & NE & E & SE & $S$ & W \\
\hline \multirow[t]{2}{*}{$A$} & EPS & 28.83 & 27.29 & 24.21 & 27.30 & 28.75 & 18.87 & In & 27.26 & 27.26 & 27.26 & 27.22 & 27.20 & 27.10 \\
\hline & EPS & 28.83 & 27.29 & 24.21 & 27.30 & 28.75 & 18.87 & Out & 30.47 & 30.48 & 30.48 & 30.46 & 30.44 & 30.39 \\
\hline \multirow[t]{2}{*}{ B } & EPS, plastic & 28.83 & 27.29 & 24.21 & 27.30 & 28.75 & 18.87 & In & 28.74 & 28.81 & 28.86 & 28.78 & 28.70 & 28.88 \\
\hline & EPS, plastic & 28.83 & 27.29 & 24.21 & 27.30 & 28.75 & 18.87 & Out & 29.55 & 29.62 & 29.61 & 29.60 & 29.55 & 29.62 \\
\hline \multirow[t]{2}{*}{ C } & EPS, metal composite & 28.51 & 34.15 & 39.57 & 34.21 & 28.51 & 39.59 & In & 28.59 & 28.76 & 28.90 & 28.76 & 28.59 & 28.90 \\
\hline & EPS, metal composite & 28.51 & 34.15 & 39.57 & 34.21 & 28.51 & 39.59 & Out & 29.54 & 29.64 & 29.70 & 29.64 & 29.54 & 29.70 \\
\hline
\end{tabular}

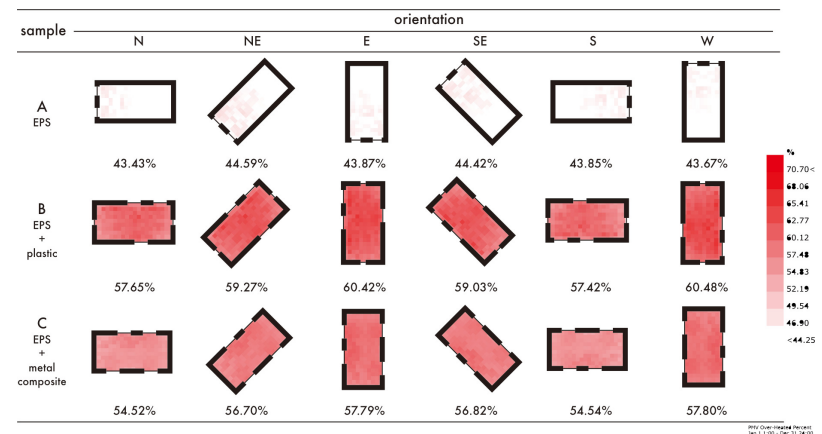

FIGURE 4. Overheated PMV results in the second round of the second stage simulation, the value generated in the simulation ranged from 44.25-70.70\%.

lation. As well as the addition or combination of EPS sandwich panel material in temporary shelter samples can have an effective impact on OTTV and PMV values. The average OTTV value can reduce up to $3.93 \mathrm{~W} / \mathrm{m}^{2}$ and comfort PMV up to $9.08 \%$, and affect indoor temperatures up to $1.37^{\circ} \mathrm{C}$.

This simulation analysis was done by comparing the materials used with the aim of providing an effective value for the materials used in each temporary shelter. The results of the data and analysis conducted by the researchers can be used as validation and modeling of temporary shelter at the later stage.

\section{ACKNOWLEDGMENTS}

This article is the result of a thesis research of the Architectural Master Program in the Faculty of Engineering, Universitas Gadjah Mada. Thanks also to all of the academic community of Universitas Gadjah Mada.

\section{REFERENCES}

Affisa FS, Djunaedi A. 2014. The effectiveness of temporary residential areas as a media recovery of post disaster Merapi 2010 case study on temporary residential areas Plosokerep, Gondangpusung, Banjarsari, and Gondanglegi [dissertation]. [Yogyakarta]: Universitas Gadjah Mada.

Akhmad AG, Fachruddin PA. 2008. Disain rumah tinggal konstruksi "knock down" (tinjauan khusus penggunaan prefabrikasi lokal) ["Knock down" construction residence design (special review of the use of local prefabrication)]. Jurnal SMARTek. 6(1):18-28.

Boen T. 2016. Belajar dari kerusakan akibat gempa bumi: bangunan tembokan nir-rekayasa di Indonesia [Learning from the damage due to earthquake wall building without engineering in Indonesia]. Yogyakarta: UGM Press.
Hariyadi A, Fukuda H, Ma Q. 2017. The effectiveness of the parametric design 'Sudare' blind as external shading for energy efficiency and visibility quality in Jakarta. Archit Eng Des Manage. 13(5):384-403. doi:10.1080/17452007 .2017.1296811.

Irwan M, Ekasiwi SNN, Bararatin K. 2016. Bangunan portabel sebagai solusi kebutuhan hunian temporer yang layak huni [Portable buildings as solution to the need for temporary shelter]. Jurnal Sains dan Seni ITS. 5(2). doi:10.12962/j23373520.v5i2.19043.

Karyono TH. 2013. Arsitektur dan kota tropis dunia ketiga: suatu bahasan tentang Indonesia [Architecture and third world tropical cities: discussion about Indonesia]. Depok: Rajawali Pers.

Mahira ED, Hignasari V. 2018. Konsep mandala pada rancangan limbah kontainer untuk hunian sementara korban bencana alam di Bali [The concept of mandala in the design of container waste for temporary resettlement of natural disaster victims in Bali]. Vitruvian. 7(2):77-86.

Moon JI, Lee SH. 2007. A Study on the planning method of temporary residences for refugees following a disaster: focused on Korean temporary residences. JAABE. 6(2):251-258. doi:10.3130/jaabe.6.251.

Olglay V. 2015. Design with climate: bioclimatics approach to architectural regionalism. New Jersey: Princeton University Press.

Pero J. 2014. Housing the displaced. Mech Eng-CIME. 136(1):10.

Putro HP, Roychansyah MS. 2012. Pembangunan huntara pasca bencana Merapi di Kabupaten Sleman [Postdisaster shelter development in Merapi in Sleman Regency] [dissertation]. [Yogyakarta]: Universitas Gadjah Mada.

Rizal FF, Tavio TT. 2014. Desain permodelan sambungan beton precast pada perumahan tahan gempa di Indonesia berbasis knockdown system [Design of precast concrete connection modeling in earthquake resistant housing in Indonesia based on knockdown system]. Jurnal Teknik ITS. 3(1):C1-C4. doi:10.12962/J23373539.V 3I1.5496.

Santoso WE, Felecia F, Panjaitan TWS. 2016. Pembuatan prototipe hunian sementara untuk pengungsi di Indonesia [Making prototype temporary protection for refugees in Indonesia]. Jurnal Titra. 4(2):235-242.

Satwiko P. 2009. Fisika bangunan [Building physics]. Yogyakarta: Andi.

Setiani AN, Harani AR, Riskiyanto R. 2017. Perhitungan Overall Thermal Transfer Value (OTTV) pada selubung bangunan [Calculation of Overall Thermal Transfer Value (OTTV) on building envelopes]. Arsir. 1(2):100-109. doi: 10.32502/arsir.v1i2.879. 